\title{
Seasonal response of Posidonia oceanica to light disturbances
}

\author{
O. Serrano*, M. A. Mateo, P. Renom \\ Centro de Estudios Avanzados de Blanes (CEAB), c/ Accés a la Cala St. Francesc, 14, 17300 - Blanes, Girona, Spain
}

\begin{abstract}
The effects of changes in the irradiance reaching a Posidonia oceanica meadow were investigated seasonally in Portlligat Bay, NW Mediterranean, by means of in situ shading experiments. The results showed that reduced irradiance during the spring-summer period (SS) had a severe impact on the physiology, morphology and structure of $P$. oceanica meadows, whereas the same disturbance during autumn-winter (AW) had no significant effect. Changes in all the variables investigated (net leaf production, $\delta^{13} \mathrm{C}$, shoot density and cover) clearly indicate that P. oceanica meadows are significantly more vulnerable to light deprivation between March and July than between September and January. During SS, leaf production in the plots under screens filtering $99 \%$ of the incident irradiance dropped by more than $80 \%$ with respect to the control plots, and plant sheath $\delta^{13} \mathrm{C}$ values dropped below $-16 \%$, with a total decline greater than $4 \%$ with respect to the control plots. Shoot density and cover were significantly reduced in the $99 \%$ shaded plots after ca. $120 \mathrm{~d}$ of shading in SS (61 and $54 \%$, respectively). However, in AW none of the shading treatments showed a significant reduction in leaf production, $\delta^{13} \mathrm{C}$ values, shoot density or cover. Shading in SS led to a significant decrease in epiphyte biomass, which may have increased the light reaching the leaves and smoothed the effects of shading. The results from this study show that coastal management activities that lead to changes in water transparency (i.e. dredging, beach restoration, sediment load, waste discharge, etc.) in the vicinity of climax seagrass ecosystems should be minimized in SS and performed during the shortest possible period in AW.
\end{abstract}

KEY WORDS: Seagrasses - Irradiance - Productivity - Stable isotopes - Shading experiments · Mortality $\cdot$ Coastal management $\cdot$ NW Mediterranean

\section{INTRODUCTION}

Posidonia oceanica (L.) Delile is a dominant endemic seagrass in Mediterranean coastal waters. Seagrass meadows form one of the most productive and complex marine ecosystems (Duarte 2001), and loss of seagrasses is now of worldwide concern (Orth et al. 2006). Perturbations, either natural or anthropogenic, can be particularly critical for climax, slow-growing seagrass species, such as $P$. oceanica, which have only longterm or no recovery capacity. Historic declines in seagrass populations worldwide have been attributed to a wide variety of human impacts, such as coastal works (e.g. Guidetti \& Fabiano 2000), industrial and urban sludge discharges (Pergent-Martini \& Pergent 1995), fish farming (Delgado et al. 1997), trawl fishing
(Sánchez-Lizaso et al. 1990), sediment level changes (Marbà \& Duarte 1997, Manzanera et al. 1998), temperature increases (Marbà \& Duarte 2010) and especially nutrient loading (Short \& Burdick 1996), most of which potentially or ultimately diminish surface irradiance. A reduction in the incident irradiance in seagrass habitats has caused large-scale losses of seagrasses, and is considered the main environmental factor that regulates their abundance and distribution (e.g. Larkum \& West 1983, Duarte 1991). The effects of reduced light on seagrass meadows have been examined using shade screens to modify the natural light climate (e.g. Ruiz \& Romero 2001, Collier et al. 2009), and along depth gradients (Dennison \& Alberte 1985, Dawes \& Tomasko 1988, West 1990, Collier et al. 2007). The results obtained so far indicate that seagrass pro- 
ductivity, growth and abundance are extremely sensitive to changes in light availability. Larger and low turnover temperate seagrass species such as $P$. oceanica or Thalassia spp. may be less resilient and also more sensitive to light reduction than smaller species (e.g. Zostera spp.) because of higher belowground biomass and higher light requirements (Backman \& Barilotti 1978, Bulthuis 1983, Abal et al. 1994, Ruiz \& Romero 2001). Light disturbances may cause long-term damage to $P$. oceanica meadows because of their low capacity to recover after a mortality event (Gordon et al. 1994, Ruiz \& Romero 2001).

Previous studies demonstrated strong seasonality of Posidonia oceanica growth with a spring maximum and a late summer minimum (Ott 1980, Alcoverro et al. 2001). Negative carbon balance occurred from fall to spring, due to both the low surface irradiance and the reduced day length, whereas positive carbon balance occurred only during the summer months (Alcoverro et al. 2001). P. oceanica is able, like other temperate seagrasses (i.e. Walker et al. 1999), to support substantial growth rates over autumn and winter by the mobilization of reserves accumulated over late summer, allowing overwintering and re-growth under conditions of negative carbon balance (Pirc 1985, Alcoverro et al. 2001). In the present study we examined the effect of light changes on physiological and structural plant variables under the hypothesis that this impact is highly season dependent.

\section{MATERIALS AND METHODS}

Field experiments. We established in situ shading treatments with a 0,80, 90 and $99 \%$ reduction in surface irradiance over undisturbed, $5 \mathrm{~m}$ deep, $1.5 \times 1.5 \mathrm{~m}$ Posidonia oceanica plots in Portlligat Bay, Cap de Creus Natural Parc (NW Mediterranean, Spain; Figs. 1 \& 2). Three screens for each treatment were placed at random over the meadow for 4 mo in 2 series of experiments (spring-summer [SS] and autumn-winter [AW]). The 2 series of experiments were separated from each other by approximately $30 \mathrm{~m}$, and were carried out in a very homogenous area of the meadow. Seagrass rhizomes were not cut around the experimental plots. Screens were made of a commercial polyester net with a known percentage of light filtration (Polysack Europa, S.L.) mounted on PVC pipe frames. The screens were maintained at approximately $50 \mathrm{~cm}$ above the bottom. All screens were brush-cleaned 2 or 3 times a month to eliminate fouling. The average light reaching the canopy was recorded every 10 min by placing an underwater light logger (StowAway LI, Onset Computer Corporation) in the centre of a plot of each light condition with the sensor $25 \mathrm{~cm}$ from the bottom. Log-

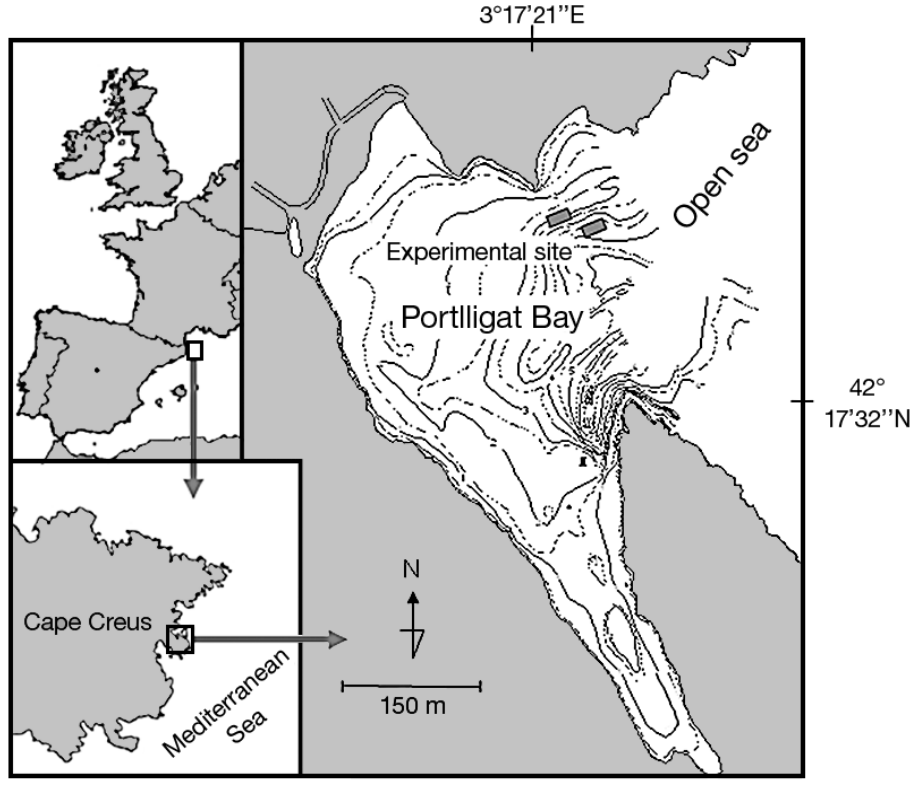

Fig. 1. Location of the study site, Portlligat Bay, Girona, northwestern Mediterranean. The experimental area occupied around $200 \mathrm{~m}^{2}$. Plots were situated at ca. $5 \mathrm{~m}$ depth

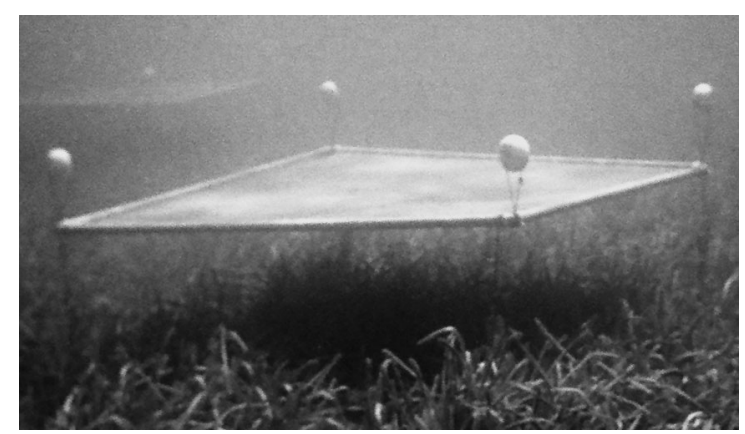

Fig. 2. In situ shading treatment of $99 \%$ light deprivation over $1.5 \times 1.5 \mathrm{~m}$ Posidonia oceanica plots in the study site

gers were either cleaned or replaced every 2 wk by SCUBA diving to prevent bio-fouling and to download data. Footcandles were transformed into photon flux density units ( $\mu \mathrm{mol}$ photons $\mathrm{m}^{-2} \mathrm{~s}^{-1}$ ), applying an empirical regression using data obtained from simultaneous records from StowAway and Li-Cor (underwater PAR spherical quantum sensor) placed to the side of the experimental site during 3 different periods during the course of a previous study (Mateo et al. 2010).

Changes in living leaf sheath $\delta{ }^{13} \mathrm{C}$ signatures, net leaf production and epiphyte biomass were determined periodically during the 2 experimental periods (SS and AW). A total of 7 sampling events during each period were performed; these were more frequent during the first month and spaced further apart thereafter until the end of the experimental period. 
Net leaf production (mg dry weight [DW] d $\mathrm{d}^{-1}$ shoot $^{-1}$ ) was evaluated by marking shoots following a modified Zieman method (Zieman 1974, Romero 1989). All leaves on a shoot were punctured together just above the ligule of the oldest outermost leaf with a hypodermic needle. At each sampling event, 10 shoots were marked in each plot, and the shoots marked in the previous visit were collected.

Shoot density and seagrass cover were randomly measured in 12 replicate quadrats $(25 \times 25 \mathrm{~cm})$ at each experimental plot before and after the exposure period. Plants were sampled within the $1 \times 1 \mathrm{~m}$ central area to maximize the consistency of the light levels and avoid any border effects.

Laboratory procedures. Carbon isotopic signatures were determined at the Scientific-Technical Services of the University of Barcelona using a Finnigan Delta S isotope ratio mass spectrometer (Conflo II interface). Isotopic values are reported in the $\delta_{\mathrm{VPDB}}$ notation and the analytical precision ranged from 0.11 to $0.06 \%$. In this study we measured $\delta^{13} \mathrm{C}$ signatures in sheaths, but in most previous studies $\delta^{13} \mathrm{C}$ was measured from Posidonia oceanica leaves (Cooper \& DeNiro 1989, Vizzini et al. 2003, Lepoint et al. 2003). We opted to use sheath tissue rather than leaf tissue because one of the goals of the present study was to obtain a transfer equation to reconstruct the production of $P$. oceanica using sheath material preserved during thousands of years in the matte (Mateo et al. 2010). We are currently studying the variability of carbon stable isotopes in the seagrass Posidonia oceanica (P. Renom \& M. A. Mateo unpubl.), and found a highly significant correlation between the isotopic compositions of leaves and their corresponding sheaths $(\mathrm{N}=30, \mathrm{r}=0.64, \mathrm{p}<0.001)$ :

$$
\delta^{13} \mathrm{C}_{\text {Leaves }}=-4.075+0.647 \times \delta^{13} \mathrm{C}_{\text {Sheaths }}
$$

This is relevant to better define which leave isotopic values represent saturation or poor carbon balance condition for the plant.

Epiphytes were removed with a razor blade, which has been shown to remove most of the epiphytes (Kirchman et al. 1984), and then 'new' (i.e. that between the reference level of the mark and the actual position of the holes) and 'old' (the rest) tissues were separated. All fractions were dried (at $60^{\circ} \mathrm{C}$ for $48 \mathrm{~h}$ ) and weighed separately. Leaf growth rate $\left(\mathrm{mg} \mathrm{DW} \mathrm{d}^{-1}\right.$ shoot $^{-1}$ ) was determined by dividing the weight of new tissue by the number of days elapsed between successive sampling events. Removal of shoots during the sampling events was accounted for in the \% shoot variation calculations.

Numerical procedures. A 2-way nested ANOVA was applied to assess the statistical significance of the effect of shading on net leaf production, $\delta{ }^{13} \mathrm{C}$ values and epiphyte biomass over the 2 experimental periods.
The experimental design consisted of 3 factors: period (SS vs AW), treatment (0, 80, 90 and $99 \%$ shading) and sampling (time elapsed). The random factors sampling and treatment were nested within period, and within period and sampling events, respectively. Post hoc comparisons of means were performed using a modification of the Tukey HSD test for unbalanced designs (i.e. unequal N HSD test) when significant effects were detected by ANOVA.

A nested ANOVA was applied to evaluate the statistical significance of the effect of shading on shoot density and cover over the 2 experimental periods. The experimental design consisted of the factors period and treatment as above, and the random factor treatment nested within period. When significant effects were detected by ANOVA, pairwise a posteriori comparisons were performed using Tukey's HSD test.

Data were not transformed or standardized before analysis. ANOVAs are usually robust enough to perform well even though the data deviate somewhat from the requirements of normality and homoscedasticity (Zar 1984). All numerical procedures were carried out using the statistics software package STATISTICA 7.1 (StatSoft).

\section{RESULTS}

The ANOVA of net leaf production and sheath $\delta^{13} \mathrm{C}$ values revealed significant differences for the 3 main factors tested in this study $(\mathrm{p}<0.001$ in all cases; Table 1). For net leaf production and $\delta^{13} \mathrm{C}$ values, significant interactions were observed between the factors sampling and period, and between the factor treatment varying as a function of the factors sampling and period. Pairwise a posteriori comparisons showed that $\delta{ }^{13} \mathrm{C}$ values of shaded plants during SS were significantly lower than undisturbed plants only after $91 \mathrm{~d}$ under $90 \%$ shading ( $<<0.001$; Fig. 3 ). At the end of the SS period (after ca. $120 \mathrm{~d}$ ), sheath $\delta{ }^{13} \mathrm{C}$ values in all shading treatments dropped significantly with respect to the controls (values below $-13.8 \%$ ). However, the lack of response to light availability and the constancy of the $\delta{ }^{13} \mathrm{C}$ values between treatments during $\mathrm{AW}$ (always around $-12 \%$; p > 0.05) suggests that the light reduction had a negligible impact on plant physiology during this period.

In contrast, post hoc tests showed that, after $43 \mathrm{~d}$ of shading in SS, only the $99 \%$ shading treatment showed a significant reduction in leaf production in relation to the controls ( $p<0.01$; Fig. 3). After $57 \mathrm{~d}$, plant growth in all treatments was significantly lower than that in the control plots ( $p<0.001$ in all cases). Thereafter, until the end of the experimental shading in SS (after ca. 120 d), leaf production in the $90 \%$ shad- 
Table 1. Summary of the 2-way nested ANOVA performed to assess the effect of the treatment (treat) $(0,80,90$ and $99 \%$ shading) and sampling (time elapsed between sampling events) on the stable carbon isotope ratios, net leaf production and epiphyte biomass of Posidonia oceanica during 2 periods: spring-summer (SS) and autumn-winter (AW). ${ }^{* * *}$ : $p<0.001$

\begin{tabular}{|c|c|c|c|c|c|c|}
\hline Variable & Effects & $\mathrm{df}$ & SS & MS & $F$ & $\mathrm{p}$ \\
\hline$\delta^{13} \mathrm{C}$ & $\begin{array}{l}\text { Sampling (period) } \\
\text { Treat }(\text { period } \times \text { sampling) } \\
\text { Sampling }(\text { period }) \times \text { treat }(\text { period } \times \text { sampling })\end{array}$ & $\begin{array}{l}12 \\
48 \\
42\end{array}$ & $\begin{array}{l}128.84 \\
167.78 \\
139.63\end{array}$ & $\begin{array}{r}10.74 \\
3.50 \\
3.32\end{array}$ & $\begin{array}{r}15.79 \\
5.14 \\
4.89\end{array}$ & $\begin{array}{l}* * * \\
* * * \\
* * *\end{array}$ \\
\hline Leaf net production & $\begin{array}{l}\text { Sampling }(\text { period }) \\
\text { Treat }(\text { period } \times \text { sampling }) \\
\text { Sampling }(\text { period }) \times \text { treat }(\text { period } \times \text { sampling })\end{array}$ & $\begin{array}{r}8 \\
34 \\
30\end{array}$ & $\begin{array}{r}72.97 \\
320.54 \\
313.39\end{array}$ & $\begin{array}{r}9.12 \\
9.43 \\
10.45\end{array}$ & $\begin{array}{l}8.58 \\
8.87 \\
9.82\end{array}$ & $\begin{array}{l}* * * \\
* * * \\
* * *\end{array}$ \\
\hline Epiphyte biomass & $\begin{array}{l}\text { Sampling (period) } \\
\text { Treat (period } \times \text { sampling) }\end{array}$ & $\begin{array}{l}12 \\
42\end{array}$ & $\begin{array}{l}2.03 \\
1.25\end{array}$ & $\begin{array}{l}0.17 \\
0.03\end{array}$ & $\begin{array}{r}25.72 \\
4.53\end{array}$ & ${ }^{* * *}$ \\
\hline
\end{tabular}

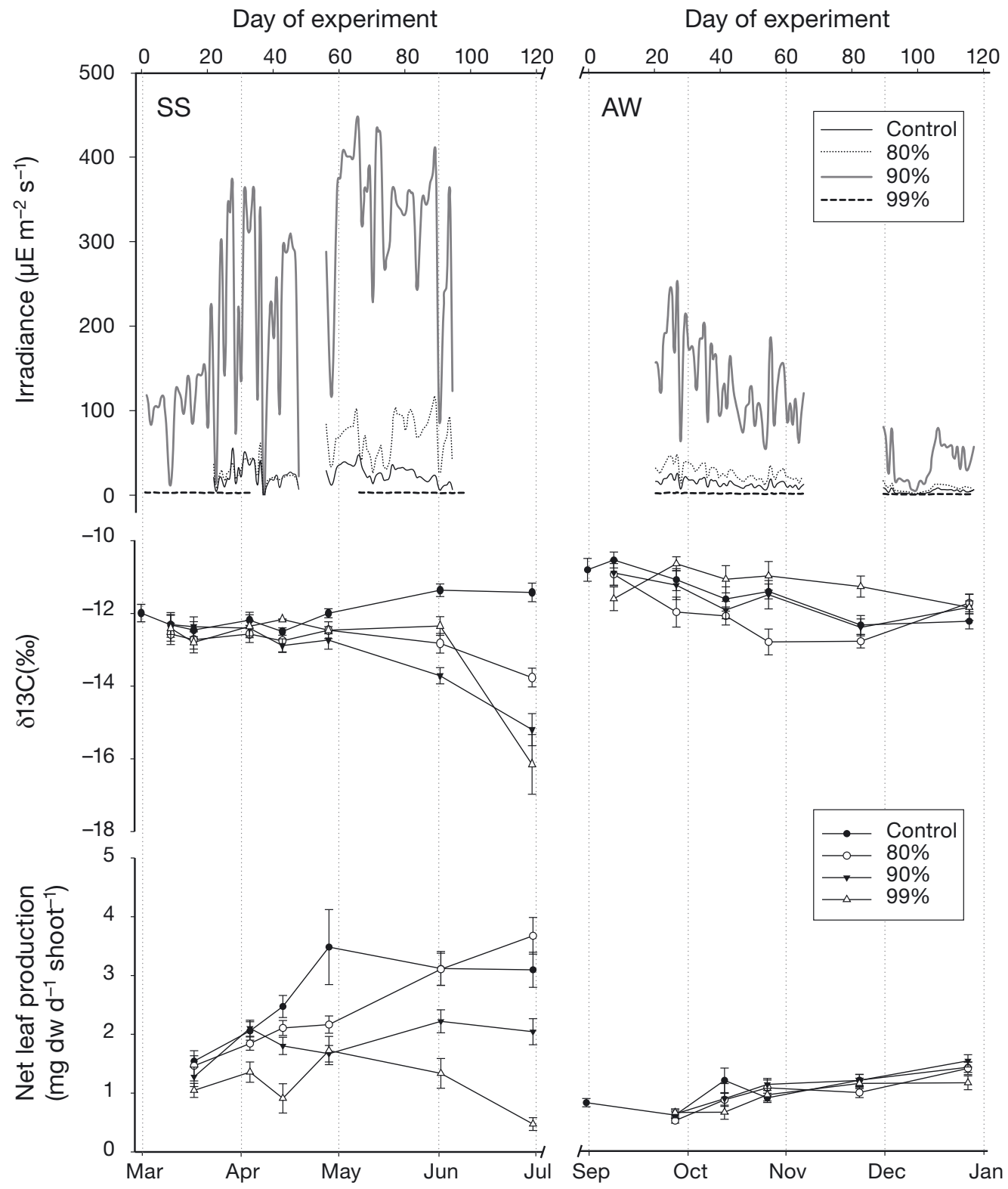

Fig. 3. Posidonia oceanica. Seasonal variations in the average irradiance, plant sheath $\delta^{13} \mathrm{C}$ values and net leaf production measured in the various shading treatments and over 2 periods: spring-summer (SS; left) and autumn-winter (AW; right). Error bars are SEM 
ing treatment continued to be low, but only the production under the $99 \%$ treatment remained significantly lower than the controls $(p<0.001)$. However, shading during AW did not cause any significant reduction in leaf production in any of the shaded plots ( $p>0.05$ ). The average leaf production in the control plots was 2.8 and $1.1 \mathrm{mg} \mathrm{DW} \mathrm{d}^{-1}$ shoot $^{-1}$ during SS and AW, respectively.

The ANOVA of epiphyte biomass revealed significant differences for the factors period and sampling $(p<0.001$ in both cases; Table 1). Despite the fact that epiphyte biomass was lower in all shaded plots (Fig. 4), pairwise a posteriori comparisons showed that epiphyte biomass from 90 and $99 \%$ shaded plants during SS were significantly lower than that from undisturbed plants only after $57 \mathrm{~d}$, and until the end of the experiment. However, shading during AW did not cause any significant reduction in epiphyte biomass in any of the shaded plots when compared with the control plots ( $p$ > 0.05), although average epiphyte biomass was always higher in control plots.

Shoot density and cover were significantly different when compared between the different periods and treatments (Table 2). Pairwise a posteriori comparisons showed that, out of all the periods and treatments, only in the $99 \%$ shaded plots during SS after ca. $120 \mathrm{~d}$ were the shoot density and cover lower than in the controls ( $<<0.05$; Fig. 5).

\section{DISCUSSION}

Although seagrasses may have compensatory mechanisms to cope with sudden changes in light availability (Dennison 1987, Ruiz \& Romero 2001), it has been shown here that light reductions higher than $90 \%$ of the incident light have a severe impact during the fast growth period (SS) in the growth and survival of shallow Posidonia oceanica meadows. However, even an extreme irradiance deprivation (99\% shading) during the slow growth period (AW) did not cause any significant decrease in leaf production, $\delta^{13} \mathrm{C}$ values, epiphyte biomass, shoot density or cover.

\section{Seasonal response of Posidonia oceanica to light disturbances}

As shown for other species (Posidonia sinuosa, Masini et al. 1995, Collier et al. 2009; Thalassia testudinum, Lee \& Dunton 1997; Amphibolis griffithii, Lavery et al. 2009), understanding the seasonal dynamics of plant growth and plant carbon resources is crucial for assessing whole-plant responses to light reduction. $P$. oceanica was considerably affected by light disturbances during SS presumably because screens emplaced matched with the plant's maximum growth and photosynthetic rates, and maximum carbon storage in the rhizomes (Pirc 1986, Alcoverro et al. 1995, Alcoverro et al. 2001, present study). In addition, plants shaded in SS were entering a period of increasing ambient light and water temperature and, therefore, higher photosynthetic demand (Masini \& Manning 1997). Higher temperatures in SS also lead to increased respiratory demand of the belowground biomass and/or cause necrosis of belowground organs in shaded plants (Alcoverro et al. 1998, Ruiz \& Romero 2001). The results of the present study support the previous finding that carbon reserve dynamics play a key role in plant performance (Gordon et al. 1994, Lee \&
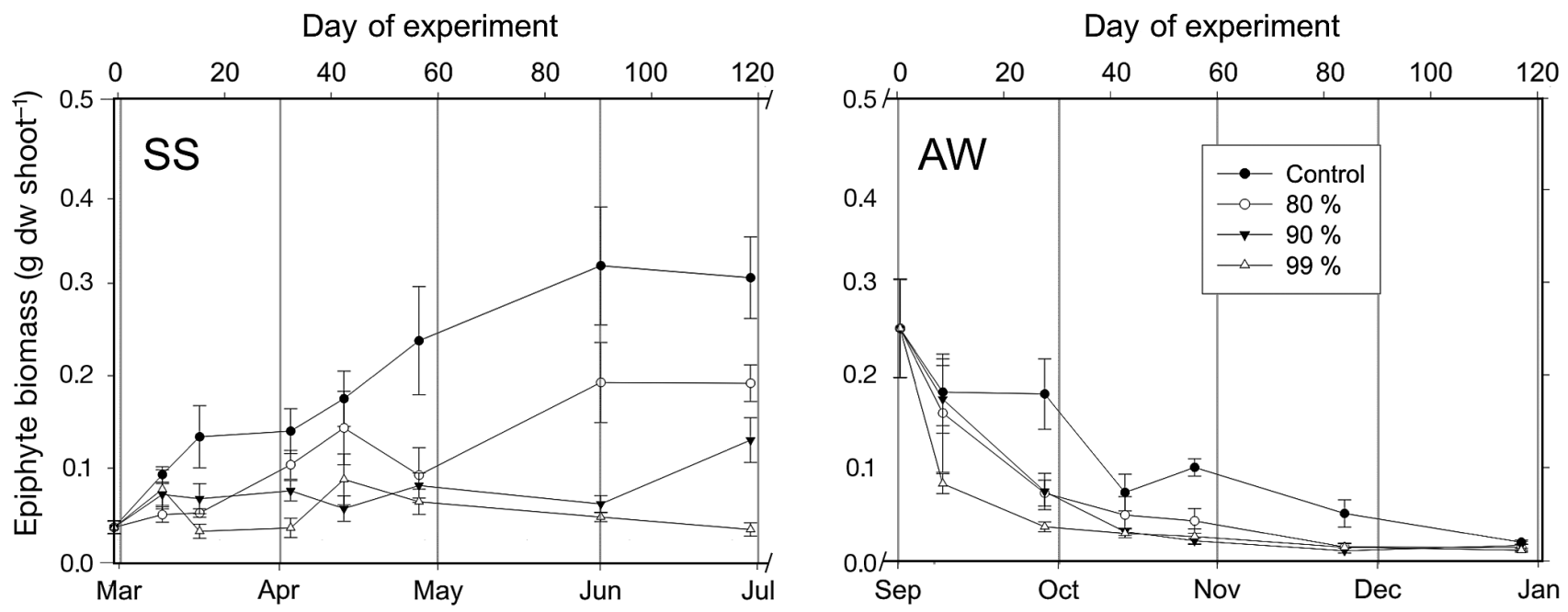

Fig. 4. Posidonia oceanica. Seasonal variations in the average epiphyte biomass in control and shaded plots measured over 2 periods: spring-summer (SS; left) and autumn-winter (AW; right). Error bars are SEM 
Table 2. Summary of a nested ANOVA performed to evaluate effect of shading $(0,80,90$ and $99 \%)$ on the shoot density and cover variables of Posidonia oceanica during spring-summer (SS) and autumn-winter (AW). ${ }^{* *}$ : $\mathrm{p}<0.01{ }^{* * *}$ : $\mathrm{p}<0.001$

\begin{tabular}{|lcccccc|}
\hline Variable & Effects & df & SS & MS & $F$ & $p$ \\
\hline Shoot density & Treat (period) & 6 & 327806 & 54634 & 4.30 & ${ }^{* * *}$ \\
Cover & Treat (period) & 6 & 4290.95 & 715.16 & 3.28 & ${ }^{* *}$ \\
\hline
\end{tabular}

Dunton 1997, Ruiz \& Romero 2001). On average, $\delta^{13} \mathrm{C}$ values of the shaded plots during SS were lower in comparison with the control plots, suggesting that in late spring the exhaustion of reserves leads to the use of carbon from ambient pools (dissolved inorganic carbon [DIC]). The decrease in the net leaf production rates is a direct result of a low photosynthetic demand, and may have also contributed to the lower $\delta^{13} \mathrm{C}$ values recorded.

Conversely, Posidonia oceanica was not substantially affected by light disturbances during AW, presumably because growth and photosynthetic rates are minimal and the carbon needs can be largely satisfied from reserve pools accumulated over late summer. This mechanism allows plant overwintering and regrowth independently of ambient light conditions (Pirc 1985, 1986, Alcoverro et al. 1995, 2001, present study). The statistical identity of $\delta^{13} \mathrm{C}$ values of the shaded and control plots reinforces this theory, and is consistent with an internal origin of the carbon used by the plant. Furthermore, shaded plants during AW maintained the same leaf production as the undisturbed plants (Fig. 3). Finally, shading treatments imposed during AW coincided with a time of declining photoperiod, water temperature and metabolic costs from non-photosynthetic organs and, therefore, light requirements to achieve a positive carbon balance.
The mean irradiance reaching the leaf canopy at natural light conditions (i.e. control plots) was $250 \mu \mathrm{E} \mathrm{m} \mathrm{m}^{-2} \mathrm{~s}^{-1}$ in SS and $92 \mu \mathrm{E} \mathrm{m}^{-2} \mathrm{~s}^{-1}$ in AW (Fig. 3); these irradiance levels allow the plant to maintain its life cycle because they are above the compensation irradiance $\left(I_{c}\right)$, as was demonstrated for a shallow Posidonia oceanica meadow $(\sim 5 \mathrm{~m})$ near the study site in summer (54 to $67 \mu \mathrm{E} \mathrm{m}^{-2} \mathrm{~s}^{-1}$ ) and in winter (6 to $38 \mu \mathrm{E} \mathrm{m}^{-2} \mathrm{~s}^{-1}$ ) months (Alcoverro et al. 1998). In the present study, the mean irradiance reaching the leaf canopy at the shaded plots during SS was 47,22 and $2 \mu \mathrm{E}$ $\mathrm{m}^{-2} \mathrm{~s}^{-1}$ in the 80,90 and $99 \%$ shaded plots, respectively. The mean irradiance reaching the leaf canopy at the shaded plots during AW ranged between 1 and $19 \mu \mathrm{E}$ $\mathrm{m}^{-2} \mathrm{~s}^{-1}$. Although these values are in the lower range of the minimal irradiance requirements for this period (Alcoverro et al. 1998), the results found here demonstrated that the plant is able to survive for $4 \mathrm{mo}$.

\section{Changes in carbon stable isotopes}

The range of $\delta^{13} \mathrm{C}$ deviation at the end of the SS experiment measured between control and $99 \%$ shaded plots was approximately $5 \%$. Depth gradients of up to $40 \mathrm{~m}$ have been reported to be necessary to yield a similar range of variation (Cooper \& DeNiro 1989). Other studies from shallow $(1.5 \mathrm{~m})$ to deep meadows (20 to $32 \mathrm{~m}$ ) have reported wider natural ranges of $\delta^{13} \mathrm{C}$ variation for $P$. oceanica leaves; the range may extend up to $10.9 \%$, including the maximum $(-8.8 \%$; Vizzini et al. 2003) and the minimum (-19.7\%; Lepoint et al. 2003). In our experiments, the lowest $\delta^{13} \mathrm{C}$ value was $-17 \%$, recorded at the $99 \%$ shading treatment in SS.
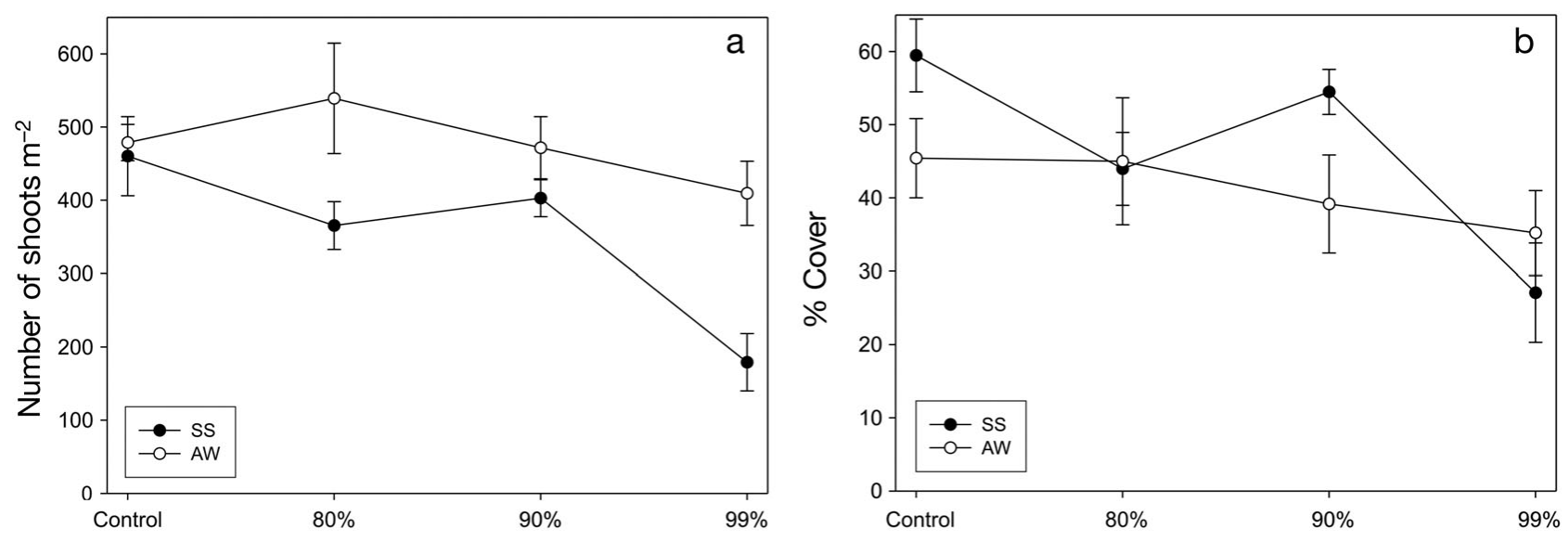

Fig. 5. Posidonia oceanica. (a) Average number of shoots and (b) percentage cover in control and shaded plots measured before and after shading experiments in spring-summer (SS) and autumn-winter (AW) periods. Error bars are SEM 
The decreased activity of the enzyme responsible for carboxylation (RUBISCO) in response to decreasing irradiance entails a higher discrimination against the heavy carbon isotope (i.e. ${ }^{13} \mathrm{C}$, Farquhar et al. 1989) and, therefore, a decrease of the $\delta^{13} \mathrm{C}$ values of the sheaths in shaded plots (more negative). Sheath carbon isotopic dynamics would probably reflect a complex model that would include an initial phase where the plant uses stored material (carbohydrate reserves), a gradual change from stored to ambient energy and, finally, the exclusive use of ambient carbon pools. The decrease in $\delta^{13} \mathrm{C}$ values in shaded plants during SS is a direct result of the very low photosynthetic rates and the use of DIC from ambient pools (Mateo et al. 2010).

The average $\delta^{13} \mathrm{C}$ value for plant sheaths from the $90 \%$ shading treatment was $-15 \%$ o whereas in control plots $\delta^{13} \mathrm{C}$ values increased to $-11 \%$. The corresponding values estimated for leaves (applying Eq. 1) were higher in the case of the $90 \%$ shaded plots $(-13.8 \%$ ) and very similar in control plots $(-11.2 \%)$. From values reported in the literature and from our results, it seems reasonable that $\delta^{13} \mathrm{C}$ values below ca. $-14 \%$ can be considered indicative of a poor carbon balance condition (Mateo et al. 2010). The absence of a significant response to light availability in AW and the constancy of the isotopic ratios may be linked to the use of plant reserves (the plant would be using carbon from internal pools) stored during the previous season (Alcoverro et al. 2001). A negligible metabolic carbon isotopic discrimination during transformation and transport of the stored materials can be assumed.

Although only marginally relevant to the main topic of this study, it might be worth mentioning that the large isotopic variability throughout the year ( 2\%o) demonstrates the necessity of an adequate knowledge of the natural isotopic variability of carbon sources for seagrass-associated herbivores before attempting to establish complex tropic links across meadow inhabitants based only upon an isotopic approach.

\section{Net leaf production, shoot density and cover}

Increased shoot loss and a rapid reduction in leaf productivity are the most commonly observed seagrass responses to in situ shading experiments (Backman \& Barilotti 1976, Dennison \& Alberte 1982, Gordon et al. 1994, Fitzpatrick \& Kirkman 1995, Lee \& Dunton 1997). Ruiz \& Romero (2001) reported high shoot mortality in Posidonia oceanica meadows after severe shading in SS. Bulthuis (1983) also reported that shoot density and net leaf production in Heterozostera tasmanica meadows decreased more rapidly during summer than during winter at reduced light levels. Net leaf production decreased at the end of the 90 to $99 \%$ shading in SS with respect to control plots (ranged between 35 and $84 \%$ ). This is a direct response to lower photosynthetic demand of the plant due to decreasing irradiance, resulting in lower net leaf productivity. It is important to note that leaf production rates are determined from only living shoots within a plot; therefore, lower areal production rates could have been obtained if a more random sampling had been performed (i.e. negative production rates) and if changes in density (i.e. mortality) had been taken into account. We could not perform these corrections as shoot density was only recorded at the beginning and at the end of the experimental periods. Although not measured, other changes in plant morphology may have occurred following shading, such as a decrease in leaf growth rate and biomass, number of leaves per shoot and shoot size (Ruiz \& Romero 2001). Leaf growth in AW was low $(<1.5 \mathrm{mg}$ DW $\mathrm{d}^{-1}$ shoot $^{-1}$ ) and similar to those rates found by other authors (Buia et al. 1992, Ruiz \& Romero 2001), probably due to general light limitation. Leaf growth was constant across treatments in AW, presumably because it was supported by internal carbon pools.

The $99 \%$ shading in SS led to the death of more than $60 \%$ of the initial number of shoots and to the loss of more than half of the coverage. Together with a decrease in leaf biomass, losses in coverage are typical depth-related changes in seagrass meadows (Olesen et al. 2002). Posidonia oceanica may respond to shading with some degree of photo-acclimatization, which tends to balance the carbon budget under low irradiance conditions (e.g. decrease in the net oxygen release at saturating irradiance, the saturating irradiance and the compensation irradiance, increase in quantum photosynthetic efficiency, and decrease in dark respiration; Ruiz \& Romero 2003). In the 80 and $90 \%$ shading treatments during $\mathrm{SS}$, no response in the shoot density and cover was observed, but leaf growth and sheath $\delta^{13} \mathrm{C}$ decreased. This is suggestive of a first reaction to important degrees of light deprivation through physiological and morphological adjustments at the irradiance levels reaching the leaves, and a later, more dramatic response to extreme deprivation through meadow structural adjustments.

In SS, epiphytic communities are dominated by photophilic algal species (Romero 1988), which are highly sensitive to light reduction (Fitzpatrick \& Kirkman 1995). A decrease in the epiphyte biomass in shaded plots would increase the incident irradiance actually reaching the leaf surface, and reduce the negative effects of light disturbances. In particular, this phenomenon may explain why $80 \%$ shaded plots in SS maintained leaf growth rates at levels similar to those of the control plots until the end of the experimental period. However, the quantitative importance of such effect remains largely unexplored (Ruiz \& Romero 2001). 
A significant impact on the physiology, morphology and structure of Posidonia oceanica shaded plots during SS was observed only at 90 to $120 \mathrm{~d}$ after the establishment of severe shading treatments (in particular, $99 \%$ shading). This suggests the existence of certain homeostatic mechanisms in the plant that make these variables temporarily independent from external factors. A plausible hypothesis is that, because the rhizomes around the experimental plots were not cut, the neighboring shoots inside the shaded plots may have subsidized the shaded ones with resources synthesized under natural light conditions. Marbà et al. (2002) found that a significant percentage of resource demand for leaf growth (3 to $13 \%$ ) can be supplied by translocation between shoots. However, the lack of response of the isotopic signatures suggests that such subsidy might have been limited. In the sampling performed at the end of May, leave production in control plots was clearly higher than in the rest of treatments and increased steadily from the beginning of the experiment. As a response of this increasing photosynthetic demand, the carbon isotopic composition of the plant should have increased accordingly (as a consequence of a lower isotopic discrimination). Instead, the $\delta^{13} \mathrm{C}$ values remained constant. Supporting the hypothesis of the limited subsidy is the fact that, at the end of the experimental $99 \%$ shading in SS, the central ca. $40 \times 40 \mathrm{~cm}$ of the plot had lost almost all the shoots. Marbà et al. (2002) also showed that the transfer of carbon and nutrients from non-shaded shoots has a limited spatial range (i.e. maximum distances of approximately $20 \mathrm{~cm}$ in $4 \mathrm{~d}$; further incubation times were not explored). In contrast, Ruiz \& Romero (2001) reported a much stronger impact for larger screens $\left(4 \mathrm{~m}^{2}\right)$ than those used in our experiment $\left(2.25 \mathrm{~m}^{2}\right)$. For example, they reported that between May and August all shoots under $70 \%$ shading had died. When compared with our study, this result suggests that shading effects can be screen-size dependent, probably as a combined consequence of underwater scattering of light, diel changes in sun elevation and lateral carbon and nutrient subsidy from adjacent shoots.

\section{CONCLUSIONS}

Light disturbances during the favorable growth season (SS) affect meadow structure and can be a significant handicap for seagrass viability in the forthcoming unfavorable growth season (AW) (Fitzpatrick \& Kirkman 1995, Lee \& Dunton 1997). Based on our results, it is recommended that light disturbances from February to August should be minimized to let the plant complete its maximum growth period and accumulate reserves for overwintering. Our results show that coastal management activities that are likely to increase water turbidity (i.e. dredging, beach restoration, sediment load, waste discharge, etc.) in the vicinity of climax Posidonia oceanica ecosystems should be performed in from September to January, and during the shortest possible period. Although this study also showed that shallow $P$. oceanica meadows can persist under a $90 \%$ reduction in incident light during 4 mo in the fast growth period (SS), it is quite likely that the impact would be much greater if shading occurs over a large meadow area (i.e. a real disturbance). Also, it is uncertain whether this meadow has been able to accumulate enough reserves for the next AW period under such light deprivation. If they have not been able to do so, the longer-term survival of the plants will be compromised. The experiment would need to be carried out with larger screens, cutting the rhizomes around the plots, and for a longer time period to confirm these hypotheses.

It should be mentioned that irradiance decreases exponentially with depth; therefore, the severity of the impact of 80 to $99 \%$ shading at $5 \mathrm{~m}$ depth (present study) may have dramatic consequences for deeper Posidonia oceanica meadows (Collier et al. 2009). Although our study focused on a Mediterranean seagrass, the findings for this species may be valid for other lowturnover temperate seagrass species (Walker et al. 1999), especially those whose survival depends on the carbon reserves accumulated during the favorable growth season (Sand-Jensen 1975, Chapman \& Craigie 1978, Pirc 1985, Dunton 1990).

Acknowledgements. This study has benefited from the valuable comments of 3 anonymous referees. This work was carried out within the projects PALEOMED (project 572 BOS2002-02247) supported by the Ministerio de Ciencia y Tecnología (MCYT) and SUMAR (CTM2006-12492/ MAR; Ministerio de Educación y Ciencia). The authors are grateful to D. Garrido, C. Guallar and L. Serrano for their valuable help during the demanding fieldwork and laboratory tasks. We thank $H$. Teixeira for providing statistical advice.

\section{LITERATURE CITED}

Abal EG, Loneragan N, Bowen P, Perry CJ, Udy JW, Dennison WC (1994) Physiological and morphological responses of the seagrass Zostera capricorni Aschers. to light intensity. J Exp Mar Biol Ecol 178:113-129

Alcoverro T, Duarte CM, Romero J (1995) Annual growth dynamics of Posidonia oceanica: contribution of largescale versus local factors to seasonality. Mar Ecol Prog Ser 120:203-210

Alcoverro T, Manzanera M, Romero J (1998) Seasonal and age-dependent variability of Posidonia oceanica (L.) Delile photosynthetic parameters. J Exp Mar Biol Ecol 230: $1-13$

Alcoverro T, Manzanera M, Romero J (2001) Annual metabolic carbon balance of the seagrass Posidonia oceanica: 
the importance of carbohydrate reserves. Mar Ecol Prog Ser 211:105-116

Backman TW, Barilotti DC (1976) Irradiance reduction: effects on standing crops of the eelgrass Zostera marina in a coastal lagoon. Mar Biol 34:33-40

Buia MC, Zupo V, Mazzella L (1992) Primary production and growth dynamics in Posidonia oceanica. PSZN I: Mar Ecol 13:2-16

Bulthuis DA (1983) Effects of in situ light reduction on density and growth of the seagrass Heterozostera tasmanica (Martens ex Aschers.) den Hartog in Western Port, Victoria, Australia. J Exp Mar Biol Ecol 67:91-103

Chapman ARO, Craigie JS (1978) Seasonal growth in Laminaria longicuris: relations with reserve carbohydrate storage and production. Mar Biol 46:209-213

> Collier JC, Lavery PS, Masini RJ, Ralph PJ (2007) Morphological, growth and meadow characteristics of the seagrass Posidonia sinuosa along a depth-related gradient of light availability. Mar Ecol Prog Ser 337:103-115

Collier CJ, Lavery PS, Ralph PJ, Masini RJ (2009) Shadeinduced response and recovery of the seagrass Posidonia sinuosa. J Exp Mar Biol Ecol 370:89-103

> Cooper LW, DeNiro MJ (1989) Stable carbon isotope variability in the seagrass Posidonia oceanica: evidence for light intensity effects. Mar Ecol Prog Ser 50:225-229

Dawes CJ, Tomasko DA (1988) Depth distribution in two Thalassia testudinum meadows in the west coast of Florida; a difference in effect of light availability. PSZN I: Mar Ecol 9:123-130

Delgado O, Grau A, Pou S, Riera F, Massuti C, Zabala M, Ballesteros E (1997) Seagrass regression caused by fish cultures in Fornells Bay (Menorca, Western Mediterranean). Oceanol Acta 20:557-563

Dennison WC (1987) Effects of light on seagrass photosynthesis, growth and depth distribution. Aquat Bot 27:15-26

> Dennison WC, Alberte RS (1982) Photosynthetic responses of Zostera marina L. (eelgrass) to in situ manipulations of light intensity. Oecologia 55:137-144

> Dennison WC, Alberte RS (1985) Role of daily light period in the depth distribution of Zostera marina (eelgrass). Mar Ecol Prog Ser 25:51-61

Duarte CM (1991) Seagrass depth limits. Aquat Bot 40: 363-377

Duarte CM (2001) Seagrass ecosystems. In: Levin SL (ed) Encyclopedia of biodiversity. Academic Press, San Diego, CA, p 254-268

> Dunton KH (1990) Production ecology of Ruppia maritima L. sl and Halodule wrightii Aschers, in two subtropical estuaries. J Exp Mar Biol Ecol 143:147-164

Farquhar GD, Ehleringer JR, Hubick KT (1989) Carbon isotope discrimination and photosynthesis. Annu Rev Plant Physiol Plant Mol Biol 40:503-537

Fitzpatrick J, Kirkman H (1995) Effects of prolonged shading stress on growth and survival of seagrass Posidonia australis in Jervis Bay, New South Wales, Australia. Mar Ecol Prog Ser 127:279-289

> Gordon DM, Grey KA, Chase SC, Simpson CJ (1994) Changes to the structure and productivity of a Posidonia sinuosa meadow during and after imposed shading. Aquat Bot 47:265-275

Guidetti P, Fabiano M (2000) The use of lepidochronology to assess the impact of terrigenous discharges on the primary leaf production of the Mediterranean seagrass Posidonia oceanica. Mar Pollut Bull 40:449-453

Kirchman DL, Mazzella L, Alberte RS, Mitchell R (1984) Epiphytic bacterial production on Zostera marina. Mar Ecol Prog Ser 15:117-123
Larkum AWD, West RJ (1983) Stability, depletion and restoration of seagrass beds. Proc Linn Soc N S W 106:201-212

Lavery PS, McMahon K, Mulligan M, Tennyson A (2009) Interactive effects of timing, intensity and duration of experimental shading on Amphibolis griffithii. Mar Ecol Prog Ser 394:21-33

> Lee KS, Dunton KH (1997) Effect of in situ light reduction on the maintenance, growth and partitioning of carbon resources in Thalassia testudinum banks ex König. J Exp Mar Biol Ecol 210:53-73

> Lepoint G, Dauby P, Fontaine M, Bouquegneau JM, Gobert S (2003) Carbon and nitrogen isotopic ratios of the seagrass Posidonia oceanica: depth-related variations. Bot Mar 46: $555-561$

> Manzanera M, Pérez M, Romero J (1998) Seagrass mortality due to oversedimentation: an experimental approach. J Coast Conserv 4:67-70

> Marbà N, Duarte CM (1997) Interannual changes in seagrass (Posidonia oceanica) growth and environmental change in the Spanish Mediterranean littoral zone. Limnol Oceanogr 42:800-810

Marbà N, Duarte CM (2010) Mediterranean warming triggers seagrass (Posidonia oceanica) shoot mortality. Glob Change Biol 16:2366-2375

> Marbà N, Hemminga MA, Mateo MA, Duarte CM, Mass YEM, Terrados J, Gacia E (2002) Carbon and nitrogen translocation between seagrass ramets. Mar Ecol Prog Ser 226:287-300

> Masini RJ, Manning CR (1997) The photosynthetic responses to irradiance and temperature of four meadow-forming seagrasses. Aquat Bot 58:21-36

> Masini RJ, Cary JL, Simpson CJ, McComb AJ (1995) Effects of light and temperature on the photosynthesis of temperate meadow-forming seagrasses in Western Australia. Aquat Bot 49:239-254

> Mateo MA, Renom P, Michener RH (2010) Long-term stability in the production of a NW Mediterranean Posidonia oceanica (L.) Delile meadow. Palaeogeogr Palaeoclimatol Palaeoecol 291:286-296

Olesen B, Enríquez S, Duarte CM, Sand-Jensen K (2002) Depth-acclimation of photosynthesis, morphology and demography of Posidonia oceanica and Cymodocea nodosa in the Spanish Mediterranean Sea. Mar Ecol Prog Ser 236:89-97

Orth RJ, Carruthers TJB, Dennison WC, Duarte CM and others (2006) A global crisis for seagrass ecosystems. Bioscience 56:987-996

> Ott JA (1980) Growth and production of Posidonia oceanica (L.) Delile. PSZN I: Mar Ecol 1:47-64

Pergent-Martini C, Pergent G (1995) Impact of a sewage treatment plant on the Posidonia oceanica meadow: assessment criteria. In: Özhan E (ed) Proc 2nd Int Conf on the Mediterranean coastal environment, MEDCOAST'95, Middle East Technical University, Ankara, p 1389-1399

> Pirc H (1985) Growth dynamics in Posidonia oceanica (L.) Delile. PSZN I: Mar Ecol 6:141-165

Pirc H (1986) Seasonal aspects of photosynthesis in Posidonia oceanica: influence of depth, temperature and light intensity. Aquat Bot 26:203-212

Romero J (1988) Epífitos de las hojas de Posidonia oceanica: variaciones estacionales y batimétricas de biomassa en la pradera de las Islas Medes (Girona). Oecol Aquat 9:19-25

Romero J (1989) Primary production of Posidonia oceanica beds in the Medes Islands (Girona NE Spain). In: Boudouresque CF, Meinesz A, Fresi E, Gravez V (eds) International Workshop on Posidonia beds. GIS Posidonie, Marseille 2:85-91 
Ruiz JM, Romero J (2001) Effects of in situ experimental shading on the Mediterranean seagrass Posidonia oceanica. Mar Ecol Prog Ser 215:107-120

Ruiz JM, Romero J (2003) Effects of disturbances caused by coastal constructions on spatial structure, growth dynamics and photosynthesis of the seagrass Posidonia oceanica. Mar Pollut Bull 46:1523-1533

Sánchez-Lizaso JL, Guillén JE, Ramos A (1990) The regression of Posidonia oceanica meadows in El Campello (Spain). Rapp Comm Int Mer Medit 32:7

Sand-Jensen K (1975) Biomass, net production and growth dynamics in an eelgrass (Zostera marina) populations in Vellerup Vig, Denmark. Ophelia 14:185-201

Short FT, Burdick DM (1996) Quantifying eelgrass habitat loss in relation to housing development and nitrogen loading inWaquoit Bay, Massachusetts. Estuaries 19:

Editorial responsibility: Hans Heinrich Janssen, Oldendorf/Luhe, Germany
730-739

Vizzini S, Sarà G, Mateo MA, Mazzola A (2003) $\delta^{13} \mathrm{C}$ and $\delta^{15} \mathrm{~N}$ variability in Posidonia oceanica associated with seasonality and plant fraction. Aquat Bot 76:195-202

Walker D, Dennison W, Edgar G (1999) Status of Australian seagrass knowledge. In: Butler A, Jernakoff P (eds) Seagrass in Australia: strategic review and development of an R \& D plan. CSIRO Publishing, Collingwood, p 1-24

West RJ (1990) Depth-related structural and morphological variations in an Australian Posidonia seagrass bed. Aquat Bot 36:153-166

Zar HZ (1984) Biostatistical analysis. Prentice Hall, Englewood Cliffs, NJ

Zieman JC (1974) Methods for the study of the growth and production of turtle grass, Thalassia testudinum König. Aquaculture 4:139-143

Submitted: July 7, 2010; Accepted: November 24, 2010

Proofs received from author(s): January 27, 2011 